\title{
THE THEORY AND PRACTICE OF RISK ASSESSMENT OF PROFESSIONAL DANGERS
}

\begin{abstract}
In the paper, on the basis of the conducted analysis of the dynamics of the spread of dangers in the context of evolutionary development of society, it is determined that the global problems have become complex, which appears in interdependence of natural, technogenic, socio-political, economic, scientific-technological and other risks. The main source of danger, at the present stage of development of society, is an industrial environment.

The analysis of known theoretical studies to appearance of dangerous is carried out and it is defined that none of considered theories can be treated as absolutely correct and generally accepted. First of all the conceptuality of given theories that is, limited practical usage, second of all the insufficient attention and underestimation of the role of the "human factor" as a fundamental factor in the process of creating dangers are the meanest drawbacks.

Notice, that in the European Countries exist around 100 differents methods of assessment of the risk of occurrence dangers, according them quantitative measurement of the risks is carried out by the three meanest methods: statistical, expert and analog.

British Standard BS-8800 (GB), risk assessment based on probability-loss matrix (GB, France, Latvia, the USA, Australia), construction of risk assessment scales (Germany, Finland), the methodology of the National Research Institute of Occupational Safety and Health (NRIOS) in Ukraine, risk score (the USA), risk assessment code (GB), method of verbal functions (European Union), assessment of occupational risks by the Elmer system, risk assessment based on requirements level ranking (OIR index) are the most often used methods for the risks evaluation. On basis of the analysis of the above mentioned methods, two main problems were identified. The first problem that exists in the risks evaluation of occurrence dangerous is the lack of a unique unified methodology.

The second problem is the underestimation of the significance of the "human factor" in the "man-machine" system. It is pointed out that due to underestimating the role of the "human factor" as a key component of risk one cannot consider any of the known risk assessment methods to be effective and universally accepted. Based on conducted research, the need for a principally new universal and effective methodology for quantitative risk assessment is identified.
\end{abstract}

Key words: human factors, risk, sustainability, Technosphere, danger, methodology

The evolutionary development of society over the last hundred years is characterized by a steady tendency to increase the size of the human population and the urbanization level, which in turn facilitate the process of technosphere intensification. From ancient times to the end of the nineteenth century, the population size did not significantly change and at the beginning of the nineteenth century it remained close to 1 billion people. However, after 100 years with the beginning of the industrial period, the population has doubled, and in about 30 's of the twentieth century - increased by a factor of three. In 1975, it exceeded 4 billion people, and in 1987 5 billion. In 1999, on October $12^{\text {th }}$, the world's population reached 6 billion people. At the average, the population of the planet is growing by about 86 million people per year, which correlates with the population of a country such as Germany. In accordance with the UN demographic forecast, in 2050 the population could approach 9 billion people.

The level of urban population, which is the direct creator of an anthropogenic environment is increasing even more significantly. If in 1830 there were about $3 \%$ of the population in cities, in $1960-34 \%$, then in 2020 the urban population can be about $60 \%$ of the total. Starting from 1970 the total population of the planet was growing at an average of $1.7 \%$, while the urban population at the same time was increasing by $4 \%$ annually. In the general background of urbanization, the number of metropolises where the anthropogenic environment is concentrated is increasing, being the main source of hazards (risks). If in 1800 only one place in the world - Beijing had a population of more than 1 million people, then in 1900, the number of such cities was 16 units, and in 2025 it is expected to be around 639. In accordance to the UN estimates, by 2020 , the total area occupied by the metropolis will be increased by 2.6 million $\mathrm{km}^{2}$ and will make about $4 \%$ of the area of the entire land [1]. The fastest growth of metropolitan areas is observed in developing countries. It should be noted that they are often built without respective investment in land development and improvement of the reliability of urban facilities and communications. This, in turn, massively increases the risk of natural and anthropogenic hazards. Taking into account the tendencies of rapid expansion of the technosphere boundaries, the complication of technologies and the restructuring of the human life environment to a complicated socio-natural-anthropogenic complex, one of the main problems that society needs to address in the 21 st century is the development of a single, universally accepted methodology for identifying, assessing and managing hazard risks. It should be emphasized that the overwhelming majority of states of the world today consider this problem as the most urgent in ensuring the implementation of the concepts both of humanity sustainable development and national security.

The objective of this work is to analyze known theories and techniques and the aspects of a perspective methodology for assessing the risk of hazards as an object of research.

The objective of this work is assumed to be achieved during the process of solving the following issues:

- analysis of the dynamics of spreading hazards in the society evolution; 
hazards;

- anthropogenic component in occurrence of

- analysis of known studies on the etiology of emerging hazards (risks);

- the role of the "human" factor in modern risk assessment techniques;

- aspect of the methodology for quantitative risk assessment.

Despite the gradual transition of the world's leading countries to the sustainable development model, which was announced at the United Nations Conference on Environment and Development in Rio de Janeiro (1992) and developed at the UN World Summit on Sustainable Development in Johannesburg, the tendencies to the spread of hazards dynamics on the global scale in the last years of the $21^{\text {st }}$ century, not only survived, but also increased.

Since the second half of the $20^{\text {th }}$ century, there has been a steady increase in the number of natural and industrial disasters caused by increasing population density and increased number of hazardous facilities which use radiation, chemical, biological, fire and explosion and other hazardous substances in their technological processes. From the $60 \mathrm{~s}$ of the $20^{\text {th }}$ century to the beginning of the $21^{\text {st }}$ century, the number of accidents at such facilities and the number of deaths in them increased by almost 62 and 10 times, respectively. The financial losses from natural and industrial disasters also grew no less dynamically. If from 1950 to 1975 the losses from them did not exceed 10-20 billion dollars per year, then since the second half of the $70 \mathrm{~s}$ of the $20^{\text {th }}$ century they were constantly increasing and by the period from 1995 to 2005 they reached the level of 200 billion dollars per year [2].

Analysis of dependencies Fig. 1 - 3 indicates the steady development of the tendencies that have been formed lately. Between 2014 and 2017, the total number of disasters has increased almost threefold, from 335 to 952 units, the total financial losses amounted to about 629 billion US dollars, and the death toll in them reached more than 600 thousand people.

In general, over the past fifty years, the number of reports of natural and anthropogenic hazards has risen by an order of magnitude more, and the number of affected people has increased by 250 times [3].

The industrial-technological revolution, which began at the end of the nineteenth century, has led to the global human intervention in all geographic environments of the Earth, especially in the lithosphere, atmosphere, and biosphere. For example, human geological activities have already exceeded the volumes of natural geological processes. Nowadays, during the construction and extraction of minerals, people move more than 100 billion tons of rocks over a year, which is approximately 4 times the mass of the material, which is carried by all the world's rivers during erosion. Anthropogenic human impact on the lithosphere leads to large-scale changes in the natural environment, it causes the occurrence of new (techno-natural) processes and phenomena, among which the largest hazard is posed by the induced seismic activity, land subsidence, underflooding and others. Technogenic impacts can accelerate the stress accumulation in the Earth crust which increase the frequency of

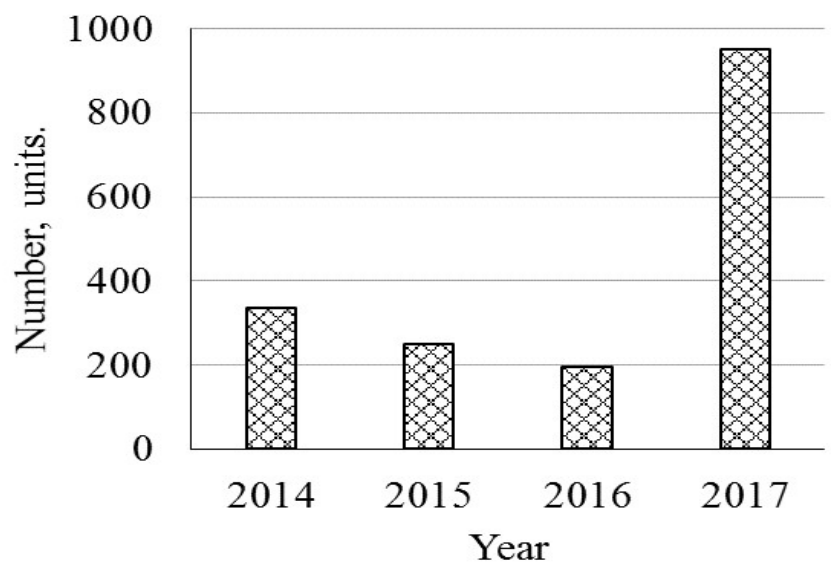

Fig. 1 - The total number of disasters

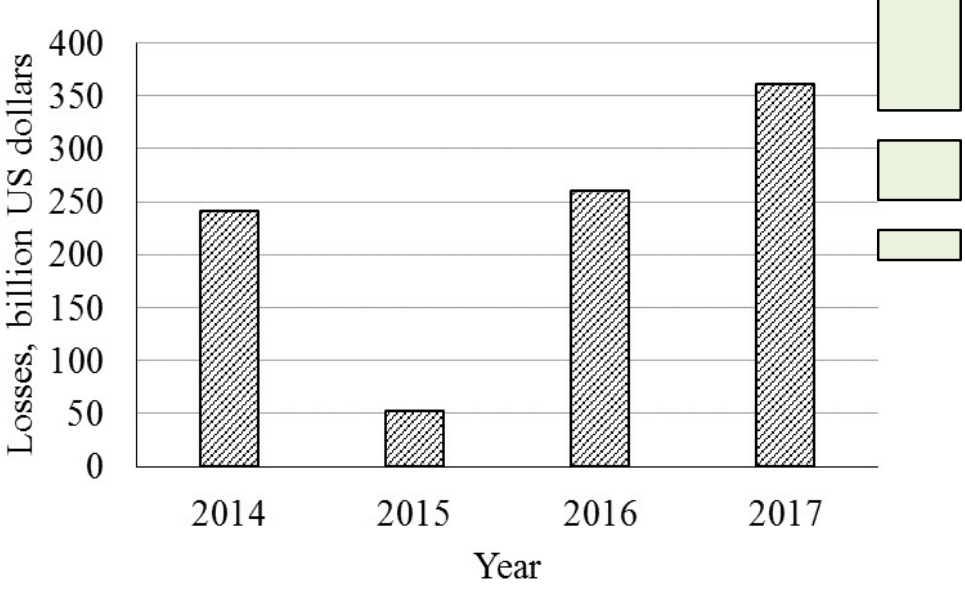

Fig. 2 - Financial losses from natural and industrial disasters

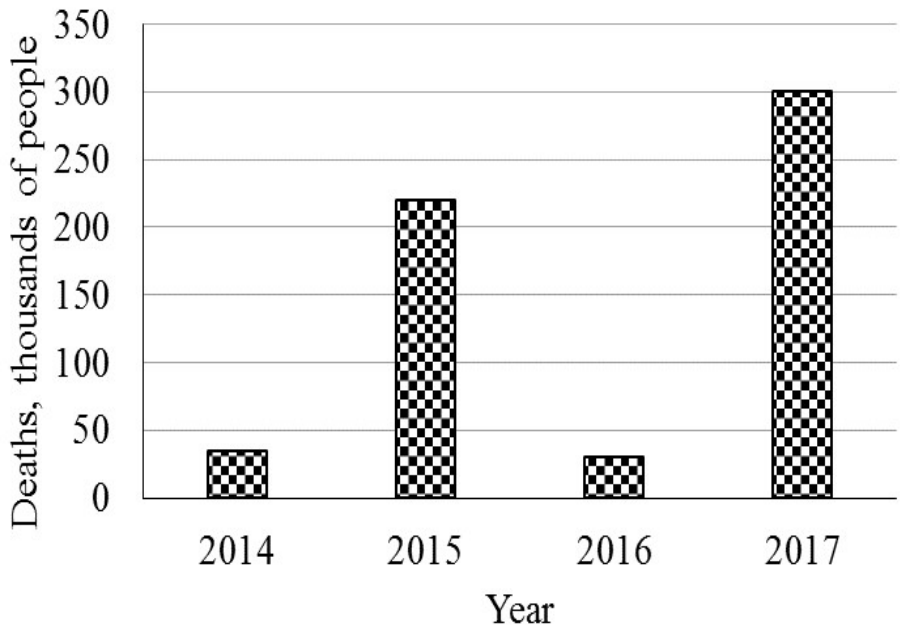

Fig. 3 - Number of deaths in natural and industrial disasters

earthquakes [4].

Anthropogenic impact on the environment conduces to climate changes, causing a concentration increase in the atmosphere of greenhouse gases, aerosols (small particles) and clouded sky. Since the beginning of the industrial era, the general effect of human activity is the global warming - about 1-1.5 degrees, which significantly exceeds by its dynamics the impact on the envi- 
ronment of natural phenomena such as changes on the Sun and volcanic eruptions. This process is particularly intensive in the last 20-25 years.

In the process of natural resource use humanity annually moves more than 4 trillion tones of substances on our planet, creates thousands of new chemical compounds, most of which are not included in the cycle of substances and eventually accumulates in the biosphere, causing its pollution [5].

The modern technically oversaturated world is in a state of unstable equilibrium when even a small false action can cause a huge on its scale and consequences industrial or natural disaster. UN data shows that anthropogenic hazards (disasters) rank third among all types of disasters by the number of deaths. Rank first is hydrometeorological disasters (floods and tsunamis), geological disasters rank second (earthquakes, volcanic eruptions, etc.). The share of the total financial loss from the consequences of industrial disasters, according to some studies, amounts from 20 to $40 \%$, and from natural disasters from 60 to $80 \%$. However, these data require, in our opinion, some refinements towards the anthropogenic component increase, since a very large number of hazards that are classified as natural ones may arise as a result of anthropogenic activity (the destruction of traditional ecosystems - floods, hurricanes, landslides, earthquakes) and vice versa (earthquake, tsunami - accident at the Fukushima NPP - 1) [6 - 10]

Industrial and to a certain extent natural disasters are based on social reasons as technical systems are designed, manufactured and managed by humans to ensure the achievement of certain socially important goals. Energy, nuclear, infrastructural, transport, ecological, space accidents and disasters are ultimately caused inconsistencies complex systems elements interaction, the creation and operation of which involves both people and elements of their technologies. Thus, there is the inevitability of building the risk society by humanity in the very structure of modern civilization.

It is very important to understand how and why the risk occurs to be able to detect and regulate the it. In various areas of human life, experts analyze the hazard phenomena and unfavorable events commonly found exactly in their specialization. Nevertheless, there has not yet been created the only general theory of risks realization, which would fully describe the causes and the process of their occurrence. It is mainly caused by a too large variety of the risks themselves and spheres of life where they occur. However, attempts to create theories that explain the behavior of certain risks groups have been made numerous times [8-10].

Studies on the etiology of hazards (risks) occurrence were developing at the beginning of the $20^{\text {th }}$ century in such well-known theories as: "Domino"; "Multiple Causation"; "Pure chance"; "Biased liability theory"; "Accident proneness"; "Symptoms versus causes"; "Iceberg" and "Energy release".

According to the Domino Theory (V. H. Heinrich 1931), it was assumed that $88 \%$ of all accidents were caused by staff erroneous actions, $10 \%$ by the unreliability of equipment and $2 \%$ by force majeure. W. H. Heinrich offered a "Five-factor sequence" of an accident, where each factor brings into action the next one, like the fall of the dominoes placed in the string of tiles. The sequence of factors includes the following: 1. Ancestry and social environment; 2 . Worker's fault; 3 . Unsafe act together with mechanical and physical hazard; 4. Accident; 5. Damage or injury. The key factor was considered the one related to unsafe act together with mechanical and physical hazard. The disadvantage of this theory can be deemed the guess that removal of at least one event (domino tile) from a chain will lead to the exclusion of the occurrence of a hazardous event. However, the positive feature of the Domino theory is undoubtedly the fact that the wrong actions of workers are more frequent cause of accidents in the workplace than the machinery breakdown.

The particular attention not to the technical aspects of risk, but to the "human factor" was unquestionably revolutionary for that time. Prevention of specifically the "dangerous behavior" of employees was considered by W.H. Heinrich as the most efficient risk reduction measure.

The Multiple Causation theory is the developed Domino theory. According to this theory, the factors giving rise to occurrence of accidents can be divided into two categories:

- behavioral - factors related to the employee, such as wrong actions, lack of knowledge or skills, as well as inadequate physical and mental condition;

- environmental factors, these include improper protection of potentially dangerous elements of equipment, as well as the destruction of equipment as a result of exploitation or erroneous actions.

The main advantage of the theory is the discovery of the fact that the basis of an accident is almost never only one single cause or wrong action.

The Pure chance theory argues that every one of any given group of employees has an equal chance of being involved in an accident. This means that there is no unambiguous sequence of events leading to an accident. According to this theory, all accidents correspond to force majeure of W.H. Heinrich and no external intervention can prevent them.

Biased liability theory is based on the view that once a worker is involved in an accident, the chances of the same worker becoming involved in future accidents are either increased or decreased as compared to the rest of workers. The positive aspect of this theory is that it considers such an aspect of the "human" factor as an experience that can lead both to an increase and to a decrease in the probability of hazards occurrence, but other aspects of this multi-faceted concept are not taken into account. This theory is in point of fact conceptual, but does not explain the concrete causes of hazards.

Accident proneness theory states that within a given group of workers, there exists a subset of workers who are more liable to be involved in accidents. The researchers could not prove this theory conclusively, since the findings were incomplete and contradictory. This theory is currently not universally accepted.

The "symptoms versus causes" theory is not so much a theory as an admonition needed to be taken into account to understand accident etiology. Usually, when investigating accidents, we concentrate upon the obvious causes and neglect the root ones. The main conclusion of 
the theory is that the wrong acts and unsafe conditions are the symptoms, but not the root causes of the accident. However, in our opinion, this is the main disadvantage of the theory, because the false actions of the employee shall be understood as a one of the manifestations of the "human" factor, which is always the root cause, not the symptom of an accident.

According to Iceberg theory, there is a proportion and dependence between the number of fatal accidents, minor accidents, incidents and events without the consequences which happen at the enterprise. This theory also argues that they all have common causes. Consequently, the investigation and analysis according to the method of studying incidents without consequences is an effective way of identifying the potential causes of accidents, as well as determining the necessary precautions.

In the 70's of the twentieth century in the United States the researcher William Haddon proposed a theory that could be used to describe the causes of the risks realization in many spheres of life, including technical, natural and even social. The uncontrolled release of energy and its impact on objects are thought of in this theory as the main cause of all dangerous accidental occurrences. At the same time, the concept of "energy" was interpreted quite broadly, covering not only the traditional "physical" types of energy (potential, kinetic, electrical, nuclear, etc.), but also the energy (motive force) of humanity, active living organisms, and so on. Proceeding from the basic idea, this theory was called the Energy release theory, which can be translated as "the theory of energy release." It allowed the denoting of several general directions (strategies) of risk management that can be applied in completely different areas. The disadvantage of the theory of W. Haddon can be failure to take account of the fact that in most cases the uncontrolled release of energy (both physical and energy of humanity) occurs due to human error - the impact of the "human" factor.

Analyzing the development path of theoretical research, we can draw the following conclusion: in the 20 s of the 20th century, insufficiently and poorly planned technological systems were considered to be the causes of accidents in the workplaces; in the $30 \mathrm{~s}$, the emphasis shifted towards human behavior (in particular, the wrong behavior in meeting safety requirements), and in the 1960s the emphasis in explaining the accident causation was transferred to the so-called "social-technical system", that is, the interaction between workers and machines.

Beginning in the 1970s, after the emergence of system theory, the hazard causation began to be analyzed in a single socio-technical, environmental and organizational context. In the studies of given times, emphasis was made on the role of the system of occupational safety management at enterprises in the prevention of accidents and occupational diseases. In particular, nowadays system defects, incorrect managerial decisions, noncompliance by the employer with the relevant requirements and a lack of work culture are often considered to be their causes rather than the hazardous actions and working conditions. Despite the diversity of theoretical studies in the field of etiology of hazards occurrence, none of them can be considered absolutely correct and universally accepted. The disadvantages of these theories can be first of all their conceptual importance, that is, the limitations of practical use, and secondly, the lack of attention and underestimation of the role of the "human" component as a fundamental factor in the process of creating hazards. Nevertheless, these theories are unquestionably necessary, although are insufficient for a full understanding of the nature of the causation of hazard risk occurrence.

Today, it is believed that there are about 100 different risk assessment techniques only in Europe, which rely on the above-mentioned theoretical studies one way or another. According to them, the quantitative risk evaluation is carried out by three main methods: statistical, expert and analog. Statistical and analog methods are used when there is a certain series of analogical cases, which is not always available. The expert method of risk assessment is based on a survey of specialists. For this purpose, a point scale of measuring the risk probability and the risk consequences is used.

In practice there are approximate methods of risk assessment, both direct and indirect. The most commonly used direct risk assessment techniques include: British standard BS-8800 (Great Britain) risk assessment based on probability-loss matrix (Great Britain, France, Latvia, USA, Australia), construction of risk assessment scales (Germany, Finland), the methodology of the National Research Institute of Occupational Safety and Health (NRIOSH), Risk assessment code (Great Britain); verbal functions (European Union).

A classic example of direct quantitative risk assessment methods is the British Standard BS-8800, which became the basis of such international documents as: Guidelines on Occupational Safety Management Systems ILO-OSH-2001 and OHSAS 18001. The BS-8800 Standard includes:

- identification of potential hazards;

- estimating the probability of each hazard realization in different variants and the expected severity of the consequences of each variant realization.

According to the BS- 8800 standard, the risk level (R) shall be calculated as follows:

$$
\mathrm{R}=\sum_{i=1}^{n} \mathrm{P} i \times \mathrm{S} i,
$$

where $\mathrm{Pi}$ - probability of each hazard realization, $\mathrm{Si}$ - severity of the consequences of each variant realization.

Such calculations are made for each of the identified hazards at each workplace. The coefficients from 1 to 5 are used to determine the hazard probability Pi (A high, $\mathrm{B}$ - average and $\mathrm{C}$ - low probability) and severity of the consequences Si (I - high, II - average and III - low severity of consequences). Herewith the risk level increases proportionately with the event probability $\mathrm{Pi}$ and the severity of the consequences $\mathrm{Si}$ and is determined according to the matrix of the risk category ( 5 - very high risk, unacceptable, 4 - high risk, unacceptable, 3 - average risk, acceptable with control, 2 - low risk, acceptable; 1 - very low risk). If the risk is estimated at levels 4 and 5 , the company shall implement preventive measures. The positive side of this technique is its ease of use in practice. And the disadvantage can be the absence of 
evaluation criterion of possible manifestations of the "human" factor in the structure of derivates of the risk calculating formula.

The possibility of direct quantitative assessment of risk without calculating event probabilities is realized in the well-known method of risk assessment based on the "probability-loss" matrix. The principle of the method is that the expert determines the rank of the probability of occurrence for each situation (for example: low probability, average probability, high probability) and a potential damage corresponding to this situation (for example: small, medium, large). This method is most commonly used in developed countries because of its simplicity. In addition, since in most developed countries, risk assessment in the workplace is a statutory obligation of the employer, its application allows the employer to comply with state regulatory requirements for occupational safety as economically as possible. The obvious drawback of this method is its exceptional subjectivity (the "human" factor). The use of this method is more appropriate in cases where enterprises with a large number of identified hazards have already developed a hazard list(register) and when there is evidence of injuries for a long period of time.

Risk assessment scale. According to this method, the level of risk shall be determined as follows:

$\mathrm{R}=\mathrm{S} \times \mathrm{E} \times \mathrm{B} \times \mathrm{P}$,

where $\mathrm{R}$ - risk level; $\mathrm{S}$ - expected loss; $\mathrm{E}$ - tendency towards hazard; $\mathrm{B}$ - the effectiveness of protection against hazards; $\mathrm{P}-$ hazard proneness.

The methodology for constructing the risk assessment scales is based on the BS- 8800 standard recommendation, yet the positive feature is the introduction to the calculation formula of derivatives such as the propensity to hazard (E) and the effectiveness of protection against hazard (B), which is an attempt to take into account a possible mistake ("human" factor). However, the practical definition of risk in accordance with this methodology is a rather inaccurate and difficult task from a practical perspective.

Risk assessment by the methodology of the National Research Institute of Occupational Safety and Health (NIOSH) is based on the assessment of the actual condition of the technical safety level of equipment, buildings (structures); compliance with the current rules, regulations and instructions of the occupational safety by the employees; an analysis which takes into account the occurrence of accidents and excesses of maximum permissible norms at workplaces or concentrations of harmful production factors over the reporting period. The risk level according to this methodology shall be determined as follows:

$$
\mathrm{P}=\mathrm{K}_{\mathrm{T}} \cdot \mathrm{K}_{3} \cdot\left(7800-\mathrm{K}_{\mathrm{o}}+\mathrm{S}_{\text {шб}}+0,1\right) \cdot 9 \cdot 10^{-7} \text {, }
$$

where $K_{\mathrm{T}}$ - coefficient of equipment technical hazard; $\mathrm{K}_{3}$ - coefficient of buildings (structures) technical hazard; 7800 - empirically determined needed maximum score at which the risk of an accident is minimal; $\mathrm{K}_{\mathrm{o}}$ - administration security; $\mathrm{S}_{\text {шб- }}$ amount of penalty points, which is evaluated on a score scale.

Coefficient of technical equipment hazard $K_{\mathrm{T}}$ shall be determined as follows:

$$
\mathrm{K}_{\mathrm{T}}=\mathrm{O}_{\text {д }} / \mathrm{O}_{3,},
$$

where $\mathrm{O}_{\text {д }}$ - number of equipment, machines, mechanisms at the site (in the structural subdivision, at the enterprise) that meet the safety requirements; $\mathrm{O}_{3}$. total number of equipment, machines, mechanisms at the site (in the structural subdivision, at the enterprise) that meet the safety requirements).

The organizational security coefficient $K_{o}$ consists of the sum of evaluation points of each statutory indicator and shall be determined as follows:

$$
K_{o}=\sum_{i=1}^{n} M_{i}=\sum_{i=1}^{n}\left(B_{y i} \times H_{i i}\right),
$$

where $\mathrm{M}_{\mathrm{i}}$ - evaluation point of the corresponding normative indicator; $\mathrm{b}_{\mathrm{yi}}-$ conditional score for the risk assessment of the relevant normative indicator; $H_{6 i}$ the implementation level of the normative indicator, equal to the ratio between the actually received and the normatively established indicators $\left(\mathrm{H}_{\phi \mathrm{i}} \div \mathrm{H}_{\mathrm{Hi}}\right)$. Conditional indicators and types of risks are determined according to reference tables. The positive feature of the NIOSH methodology can be considered an attempt to take into account such an important component as a "human" factor in the process of risk detecting (however not in the full extent), but the complexity and cumbersomeness of the implementation of this process may lead to a certain amount of errors in performing calculations. It should be noted that these calculations require a large amount of statistical data that is not always available. Also, the statistical data for the reporting periods, in our opinion, cannot be considered reliable for future risk calculations, since they are not stable.

Risk score method - Risk accounting. This method was developed in the USA and according to it the risk shall be calculated as follows:

$$
\mathrm{R}=\mathrm{S} \times \mathrm{E} \times \mathrm{P} \text {, }
$$

where: $\mathrm{R}$ - risk; $\mathrm{S}$ - potential consequences of hazard; E - hazard exposure time; P - hazard occurrence probability.

Risk assessment code methods shall determine risk as follows:

$$
\mathrm{R}=\mathrm{S} \times \mathrm{P}
$$

where $\mathrm{R}$ - risk; $\mathrm{S}$ - potential losses; $\mathrm{P}$ - probability. There are four degrees for the likelihood of event occurrence according to this method $\mathrm{P}$ (probable, remote, extremely remote and extremely improbable and potential losses - S (unacceptable, unfavorable, low and acceptable).

The risk assessment code methods and risk accounting methodology is a reflection of the classical risk assessment methodology in the BS-8800 standard.

Verbal functions method consists in the fact that each quantitative value of the likelihood of event occurrence is put in correspondence with a verbal description of the completely particular situation. Herewith every time while describing any given likelihood one must be guided by the following rules: any situation that does not correspond to this description corresponds to another description, in other words the same situation can lead to various consequences: from light injury to death. There are only two results taken into account while calculating: the most probable and most unfavorable ones. The risks are evaluated for each result. The calculation takes a greater risk. If reducing of both risks requires different 
protective measures, then both risks need to be taken into account. In this case, the risk is assessed without estimating the frequency of the probable event. The matter point of the approach is as follows: if the exception of the unfavorable result is not guaranteed, then this result is bound to come sooner or later. The advantage of this technique is the practical exclusion of subjectivity in assessing the likelihood of events occurrence and their consequences, but this method requires very careful preliminary work and very high qualifications of experts. Moreover, it is arguable that this evaluation will be consciously overestimated, and the complete elimination of risk can only be achieved by eliminating the source of risk.

Indirect risk assessment methods do not involve the direct detection and identification of hazards in the workplace and in carrying out the production operations. The most common indirect methods for assessment of hazard occurrence risk include the assessment of occupational risks under the Elmeri system; risk assessment based on ranking of requirements level (OIR index).

Elmeri system is the easiest indirect method of quantitative risk assessment, which does not directly affect the detection of workplace hazards. The disadvantage of the method is that all factors that affect the work safety are assumed to be equivalent. Despite this, the use of Elmeri's system allows planning of occupational safety measures to eliminate identified inconsistencies. For a more adequate risk assessment, an improved version of the Elmeri system - the OIR index is used. By analogy with the Elmeri index, the index that is being investigated is expressed as the ratio of "corresponds" - "does not correspond" The discrepancies are classified by three ranks: items $\mathrm{O}$ - contain obligatory safety requirements, the non-compliance of which can directly lead to the hazard; items I - contain important safety requirements, the failure to comply with which does not directly lead to hazards, but can lead to the encumbrance of the consequences of a hazardous event; Points with index $\mathrm{R}$ contain recommendations on work places arrangement and working process. The implementation of each item $\mathrm{O}, \mathrm{I}, \mathrm{R}$ is estimated at 3,2 , and 1 points, respectively. Risk assessment by the OIR index allows you to more accurately assess the actual rick level and indicate the measures to be taken first of all, as well as measures with the most expected effectiveness. The OIR index, as well as the Elmei's index, is not directly related to the presence and assessment of specific risks in the workplace and is based on the assumption that the severity of the consequences associated with potential hazards is already taken into account in health and safety requirements by referring them to certain levels of the labor protection system (state, industry, inter-industry normative legal acts, etc.).

Thus, if we analyze the above methods, we can distinguish two main problems. The first problem that exists in assessment of hazards occurrence risks is the lack of a single unitized methodology. The second and perhaps the main problem is that these techniques indicate the need to consider the "human" factor, as one that "may" affect the risk level. The "human" factor in them is interpreted as: the interaction between a human and a machine; interconnection between people; psychological and ergonomic aspects; the capacity for recognition of danger in a particular situation, which depends on the experience level, education and abilities of a person. The authors emphasized the word "may" as something minor not without a reason, because in our opinion the main disadvantage of all modern methods of risk detecting is an underestimation, and in some cases a misunderstanding of the significance of the "human" factor as the key factor of any risk, including the industrial one. [2]

The mistake ("human" factor) is being laid during the process of creating the technosphere at each stage - from idea to implementation and operation and directly depends on the actions of a human as the main creator of the technosphere. It is also fair to think that there is a mistake in the very methodology of all known methods for risk assessment whether expert or statistical or ana$\log$. That is why we have no reason to consider any of the well-known methods to be perfect and satisfy the modern requirements of ensuring occupational safety, in identifying and assessing risks at all stages of their formation.

The past and future periods of evolution have always been and will be associated with the development of a anthropogenic environment. Considering the concept of sustainable development of humanity, which the modern progressive society seeks to achieve, the issue of ensuring the safety of the human and the harmonious coexistence of the technosphere and the natural environment becomes urgent. And this is impossible without the creation of a fundamentally new, universal and effective methodology of quantitative assessment of the hazard occurrence risk.

The scientific aspect of this problem is the scientific substantiation of the integral criterion of quantitative risk assessment on the basis of the components of the complex criterion of estimating the "human" factor and the complex criterion that objectively evaluates the working conditions.

The complexity of the scientific problem involves multicomponent and multifactority of the specified complex criteria, the definition of which is possible only with the use of the mathematical technical cybernetics apparatus.

The development and further implementation of a new methodology for quantitative risk assessment will allow to objectively reduce existing risks at all stages of their formation and improve the modern system of occupational safety management, which today is not an effective instrument for the reduction of industrial risks and in real life most often performs the role of observer.

The conducted researches allow to draw the following conclusions:

1. Since the second half of the twentieth century, global threats have gained an integrated nature, manifested in the interdependence of natural, industrial, political, economic, social, environmental and technical-scientific risks.

2. The modern stage of society evolutionary development produces a positive dynamics of the spreading hazards, the main source of which is the anthropogenic environment.

3. Known theoretical studies on the etiology of hazards (risks) are inherently conceptual and therefore

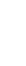


their practical utility for the prevention of accidents is limited.

4. The underestimation of the "human" factor role as a key component of risk does not make it possible to consider any of the known risk assessment methods to be effective and universally accepted.

\section{REFERENCES}

1. Netrebskyi, O. A., Bochkovskyi, A.P. (2013) Teoretychni ta praktychni aspekty otsiniuvannia ryzyku vynyknennia nebezpek [Theoretical and practical aspects of exposure risk assessment]. Khranenye y pererabotka zerna, 6 (171), 67-73. doi: 10.13140/RG.2.1.3795.9446

2. Bochkovskyi, A. P. (2015). "Lyudskyy faktor» ta ryzyk vynyknennya nebezpek: vypadkovist chy zakonomirnist. [The "human factor" and the risk of hazard: coincidence or regularity]. Yurydychna literature, 132.

3. Available at: http://www.swissre.com/

4. Vestnyk rossyiskoi akademyy nauk (2001), 4 (71), 291-302.

5. The Intergovernmental Panel on Climate Change Available at: http://www.ipcc.ch/

6. Bochkovskyi, A. P. (2016). Teoretychni aspekty universalizatsiyi otsinky profesiynoho ryzyku $v$ systemakh upravlinnya okhoronoyu pratsi [Theoretical aspects of univarsalization of professional risk evolution in occupational health and management systems]. Bulletin of the Lviv State University of Life Safety, 14, 134-151. doi: 10.13140/RG.2.2.22043.87848

7. Bochkovskyi, A. P., Sapozhnikova, N.Yu., Gogunskii, V. D. (2017). Legal and organizational issues of improving the labor protection and industrial safety level at the Ukrainian enterprises. Scientific Bulletin of National Mining University, 5 (161), 100-108. doi:10.13140/RG.2.2.33613.23528 (Scopus)

8. Bochkovskyi, A. P., Sapozhnikova, N.Yu. (2018). Improving methodology of risk identification of occupational dangerous. Grain Products and Mixed Fodder's, 18 (1), 4-8 doi:10.15673/gpmf.v18i1.895

9. Bochkovskyi, A. P., Sapozhnikova, N.Yu., Gogunskii, V. D. (2016) Labour protection and industrial safety in Ukraine: problems of transition period and perspective ways of development. Grain Products and Mixed Fodder's, 4 (64), 42 - 50 doi:10.13140/RG.2.2.20894.13126

10. Bochkovskyi, A. P., Sapozhnikova, N.Yu. (2017). Naukovo-praktychni aspekty minimizatsii ryzykiv vynyknennia profesiinykh nebezpek [Scientific and practical aspects of minimizing the risks of professional dangers]. Ekolohichna bezpeka ta zbalansovane resursokorystuvannia, 2 (16), 92-101 doi:10.13140/RG.2.2.36574.13124

А.П. БОЧКОВСБКИЙ ${ }^{1}$, канд. техн. наук, доцент, Н.Ю. САПОЖНІКОВА ${ }^{2}$, канд. техн. наук, ст.викладач

${ }^{1}$ Одеський Наиіональний Політехнічний Університет, Одеса

${ }^{2}$ Одеська Національна Академія Харчових Технологій, Одеса

\section{ТЕОРІЯ I ПРАКТИКА ОЦІНЮВАННЯ РИЗИКІВ ВИНИКНЕННЯ ПРОФЕСІЙНИХ НЕБЕЗПЕК}

\section{Анотація}

У статті, на основі проведеного аналізу динаміки поширення небезпек у контексті еволюиійного розвитку суспільства, визначено, щуо глобальні загрози набули комплексного характеру, який проявляється у взаємозалежності природних, техногенних, соціально-політичних, економічних, науково-технічних та інших ризиків. Основним джерелом виникнення небезпек, на сучасному етапі розвитку суспільства, є техногенне середовище.

Проведено аналіз відомих теоретичних досліджень щзодо етіології виникнення небезпек (ризиків) та визначено, що жодна з розглянутих теорій не може вважатися абсолютно вірною та загальновизнаною. Основними недоліками даних теорій можна вважати по перше їх концептуальність, тобто обмеженість щзоо практичного використання, а по друге недостатню увагу та недооиінку ролі «людського фактора», як основоположного чинника у прочесі створення небезпек.

Зазначено, щзо у краӥнах СС існує близько 100 різних методик оцінювання ризику виникнення небезпек, згідно з якими кількісний вимір ризику проводиться трьома основними методами: статистичним, експертним i аналоговим. До найбільи розповсюджених методик оиінювання ризиків відносяться: британський стандарт BS-8800 (Великобританія); оцінка ризиків на основі матриці «ймовірність-збиток» (Великобританія, Франція, Латвія, США, Австралія); побудова графи очінки ризику (Німеччина, Фінляндія); методика Національного науково-дослідного інституту охорони прачі (ННДІОП) в Украӥні; Risk score (США); Risk assessment code (Beликобританія); метод вербальних функиій (Європейський Союз), оцінку професійних ризиків за системою Елмері; оцінку ризиків на основі ранжирування рівня вимог (індекс ОВР).

На основі аналізу вищезазначених методик виявлено дві основні проблеми. Перша проблема, яка існує при оиіниі ризиків виникнення небезпек - відсутність єдиної уніфікованої методології. Друга проблема - недооцінка значущзості «людського фактора» в системі «людина-машина». Підкреслено, шзо недооиінка ролі «людського фактора», як ключової складової ризику, не дає право вважати жодну із відомих методик оцінки ризику ефективною та загальновизнаною.

На основі проведених досліджень, визначено необхідність створення принципово нової, універсальної та ефективної методології кількісної очінки ризику.

Ключові слова: людський фактор, ризик, сталий розвиток, техносфера, небезпека, методологія. 


\title{
ЛІТЕРАТУРА
}

1. Нетребський, О.А. Теоретичні та практичні аспекти оцінювання ризиків виникнення небезпек [Текст] / O.A. Нетребський, А.П. Бочковський // Хранение и переработка зерна, 2013. - № 6. - Том 171. - С. 67 - 73 . doi: 10.13140/RG.2.1.3795.9446

2. Бочковський, А.П. «Людський фактор» та ризик виникнення небезпек: випадковість чи закономірність. [Монографія]. Одеса, Юридична література, 2015. - С. 136.

3. Електронний ресурс: http://www.swissre.com/

4. Вестник российской академии наук, 2001. - 4 (71). C. 291-302.

5. The Intergovernmental Panel on Climate Change. [Електронний pecypc]. Режим достуny: http://www.ipcc.ch/

6. Бочковський, А.П. Теоретичні аспекти універсалізачії очінки професійного ризику в системах управління охороною праці [Текст] / А.П. Бочковський // Вісник Львівського державного університету безпеки жсттєдіяльності, 2016, № 14. - C.134-151 doi: 10.13140/RG.2.2.22043.87848

7. Bochkovskyi, A. P. Legal and organizational issues of improving the labor protection and industrial safety level at the Ukrainian enterprises [Text] | A.P. Bochkovskyi, N.Yu. Sapozhnikova, V. D.Gogunskii II Scientific Bulletin of National Mining University, 2017. - № 5 (161). - P.100-108 doi:10.13140/RG.2.2.33613.23528 (Scopus)

8. Бочковський, А.П. Удосконалення методології ідентифікаиії ризиків виникнення професійних небезпек [Текст] / А.П. Бочковський, Н.Ю. Сапожнікова // Зернові продукти $і$ комбікорми, 2018. - № 18 (1). - С. 4-8 doi:10.15673/gpmf.v18i1.895

9. Bochkovskyi, A. P. Labour protection and industrial safety in Ukraine: problems of transition period and perspective ways of development [Text] | A.P. Bochkovskyi, N.Yu. Sapozhnikova, V. D.Gogunskii II Grain Products and Mixed Fodder's, 2016. - Vol. 4 (64) - P. 42 - 50 DOI:10.13140/RG.2.2.20894.13126

10. Бочковський, А. П. Науково-практичні аспекти мінімізації ризиків виникнення професійних небезпек [Текст] / A. П. Бочковський, Н.Ю. Сапожнікова // Екологічна безпека та збалансоване ресурсокористування, 2017. - № 2 (16) C. 92-101 DOI:10.13140/RG.2.2.36574.13124

$$
\begin{array}{r}
\text { Надійшла 08.05.2018. До друку 26.05.2018 } \\
\text { Адреса для переписки: } \\
\text { вул. Канатна, 112, м. Одеса, } 65039
\end{array}
$$

\section{FEATURES OF THE TECHNOLOGICAL LINE OF} THERMAL PROCESSING OF SMALL-SEEDED CROPS

\begin{abstract} corn. developed.

\section{Introduction}

High-quality grain storage is possible only in case of thorough understandingof processes, with precise consideration of physiological properties, occurring in grain masses at all stages of their postharvesting processing anf following storage. Especially a lot of problems occur with small-seeded crops (sorghum, turnip, mustard, linen, poppy etc.), for many of them there are not enough recommendations of
\end{abstract}

Despite successes, many problems are encountered with small-seed crops (sorghum, turnip, mustard, linen, etc.), for many of them there are not enough recommendations of regulations and other normative and technological documentation. The article is devoted to ways of improving the drying process of freshly harvested grain. It is known that during post-harvest processing, small-seeded crops undergo a certain thermal effect at certain stages of it. First of all, this regards, drying and cooling processes. Meanwhile, heat treatment is a complex technological process in which numerous physical-mechanical and biochemical changes, sometimes irreversible, occur in oil seed. In addition, heat treatment is the most energy-efficient.

Timely and proper drying of grain not only increases its stability during storage, but also improves food and seed quality of grain. As a result of drying, post-harvest maturing is accelerated, humidity is leveled and technological properties change. Drying has a positive effect on the yield and quality of grain and products of its processing. To our regret, there are almost no studies of drying process of small-seeded crops grown in Ukraine. Meanwhile, drying is an important link in the post-harvesting process of

The paper gives recommendations on drying technology of crops (sorghum) and oilseeds (turnip, mustard, flax) of smallseeded food crops in grain-harvesting enterprises. The basic scheme of technological line of heat treatment of small-seeded crops and recommendations for reducing energy intensity and increasing the efficiency of heat treatment and improving their quality are

The main purpose of this article is to familiarize a wide range of specialists in the field of post-harvest processing and storage of grain with drying regimes and the scheme of technological drying line of small-seeded crops.

Keywords: moisture content of grain, small-seeded cultures, post-harvesting processing, heat treatment, drying

regulations and other normative and technological documentation.

The considered crops refer to so-called smallseeded crops (SSC) because of their geometric sizes and low weight of 1000 grains (up to $6 \mathrm{~g}$ of oilseeds, $25 \mathrm{~g}$ of grain seeds). Firstly, this forces to adjust technological modes of their post-harvest treatment substantially [1].

Wet and damp SSC should be cleaned and dried before placing them into storage. For safe storage of 